\title{
HARGA TRANSFER DAN TINGKAT PAJAK YANG EFEKTIF: KESAKSIAN DARI PERUSAHAAN MULTINASIONAL YANG TERDAFTAR DI NIGERIA
}

\section{TRANSFER PRICING AND EFFECTIVE TAX RATE: EVIDENCE FROM LISTED MULTINATIONAL COMPANIES IN NIGERIA}

\author{
Tajudeen Adejare Adegbite ${ }^{1}$, Bojuwon Mustapha ${ }^{2}$, Sanni Mubaraq ${ }^{3}$ \\ ${ }^{1}$ Department Of Accounting Al- Hikmah University, ${ }^{2}$ Department Of Accounting And Finance \\ Fountain University Osogbo, ${ }^{3}$ Department Of Accounting And Finance Kwara State University, Malete. \\ 1adetajud@yahoo.com, ${ }^{2}$ bojuwon2009@gmail.com, ${ }^{3}$ mubaraq.sanni@kwasu.edu.ng
}

\begin{abstract}
Abstrak
Penelitian ini menguji pengaruh Transfer Pricing terhadap tarif pajak efektif perusahaan multinasional terpilih di Nigeria. Data sekunder diperoleh dari laporan tahunan yang diterbitkan perusahaan multinasional terpilih yang terdaftar di bursa saham Nigeria dari 2009 hingga 2018. Hasil analisis data panel menunjukkan bahwa ukuran perusahaan, leverage, aset tidak berwujud, harga Transfer berpengaruh negatif signifikan terhadap tarif pajak efektif di Nigeria. Ini meramalkan bahwa perusahaan menggunakan Harga Transfer, Leverage, Ukuran Perusahaan, dan Aset Tidak Berwujud untuk menghindari atau mengurangi tarif pajak efektif di perusahaanperusahaan Nigeria. Juga, sebagian besar perusahaan yang dikutip secara taktis menetapkan harga transfer antar perusahaan buatan untuk memfasilitasi penghindaran pajak perusahaan.
\end{abstract}

Kata Kunci: Ongkos transfer, Pengaruh, Ukuran Perusahaan, Tarif pajak efektif, Aset Tak Berwujud

\section{Abstract}

This study examined the effect of Transfer Pricing on Effective tax rate of selected multinational companies in Nigeria. Secondary data were obtained from annual published reports of selected multinational companies listed in Nigeria stock exchange from 2009 to 2018. The panel data analysis results showed that firm size, leverages, Intangible asset, Transfer pricing had negative significant effect on effective tax rate in Nigeria. This predicted that company utilised Transfer Pricing, Leverage, Firms Size, and Intangible Assets to eschew or reduce effective tax rate in Nigerian firms. Also, most of the quoted firms tactically setting an artificial intercompany transfer prices in order to facilitate corporate tax avoidance.

Keywords: Transfer Pricing, Leverage, Firms Size, Effective Tax rate, Intangible Assets

\section{INTRODUCTION}

Among the many steps being taken by the regulatory authorities in Nigeria towards rectifying some of the oddities in the Nigerian business environment is the introduction of the transfer pricing policy. Singh (2008) described transfer pricing as a system, law and practices utilized by companies to ensure that goods and services to be shifted amongst related parties which based on standardized prices, so that profits are appropriately recognized by the respective tax authorities. Currently, transfer pricing has become one of the central points of international tax considerations around the world. This is due to the influence it exerts on the profits reported for the purpose of assessing tax liabilities of multinational companies in the different reporting jurisdictions.

An aggressive transfer pricing activities could be reflected by the extensive non- arm's length methods, non-compliance with established rules and standards during related party transactions, and even subtly usurp loopholes within the legal frameworks of different jurisdictions. Specifically, Swenson (2001) contended that transfer pricing adjustment reduces tax burdens of MNCs by shifting their assessable profit from a high tax laden jurisdiction to a more favourable tax environment, thereby reducing revenue generation of the affected countries. Pendse (2012) however argued that other strategic reasons, such as movement of funds for global business objectives account for management of tax liability using transfer pricing by MNCs. Keuschnigg and Devereux (2013) further explained that the arm's length principle, though could increase revenue generation to the 
host economy, but it risks the inflow of Foreign Direct Investment (FDI) that may serve to increase the welfare packages of her citizens in the long run.

In Nigeria, regulations on TP became effective in 2012. Oyedele et al (2013) highlighted that the promising and robust economic outlook of the Nigerian market are driving arrays of MNCs to tap into the endowed human and natural resources of the nation. Given the sophistication of these MNCs and their influx into a developing economy like Nigeria whose corporate governance codes, especially as it borders on disclosure and transparency, are still in their infancy, shifting of profits within related parties across jurisdictions via the veil of transfer pricing remains a potential threat to revenue generation by the relevant tax authority in Nigeria.

In fact, Nwogugu (2014) reported that transfer pricing risk has been on the increase which has prompted the Federal Inland Revenue Services Board to compulsorily mandate MNCs to provide information related to their transfer pricing activities. In the wake of these realities, Federal Inland Revenue Services (FIRS) in September 2012 in Nigeria , came up with the transfer pricing regulations to ensure adequate pricing of intracompany transfer of goods and services. The recent amendments are with regard to the thin capitalisation which have created a degree of commercial uncertainty for MNEs (Kabir, 2012).

Additionally, Isau ( 2014) reported that the risk review from transfer pricing over the years have shown that multinational companies in Nigeria indulged on transfer pricing manipulation for an obvious reason of profit maximization via tax avoidance. These are evident in the changes made to accounting book entries of the companies so as to transfer millions of Naira of tax liabilities into profits. According to the estimate prepared in the late 1990s, the multinational transaction undertaken in and out of the African continents mispriced through transfer pricing abuses resulted in about seven percent capital flight component totalling over 11billion USD annually in prices. It was also evident that between the year 1980 and 2009, a total um of $\$ 597$ billion to $\$ 1.4$ trillion in net resources away from the African economy (Hopwood, 2013).

Given the linkage of the recent banking crises that almost crippled financial activities in the Nigerian business environment to mispricing of products and services among related firms, coupled with Nigeria's active participation in global trade of goods and services, (Alabi Oyeranti, Adetunji Babatunde, \& Olawale Ogunkola, 2011), it is expedient to analyse how transfer pricing affected the effective tax rate viz-a-viz their profits prior to the introduction of the transfer pricing policy. According to Cunningham, 2014; Elitzur and Mintz, 1996; McDonald, 2008; Pearson, 2005), most of the multinational companies structured the payment of intra companies' transaction to facilitate tax avoidance by tactically and clandestinely setting an artificial inter-company transfer prices. Richardson, Taylor, and Lanis (2013) explored five explanatory variables to ascertain the aggressiveness of Australian firms with respect to transfer pricing. They include firm size, profitability, leverage, intangible assets and multinationality. Consequent upon the studies, Yao (2013) justified a model that the enforcement of arm's length principle on MNCs does not necessarily lead to an increase in revenue generated from tax. According to him, transfer pricing activities by MNCs are not necessarily done for tax liability manipulations. Most of the Multinational companies have been accused of lower tax subscriptions to the government purse which translated that, because of many department and subsidiaries in MNCs, transfer price has been employing to reduce their assessable profits drastically which is tantamount to tax payable reduction. It has been stated that most of the resident corporate organisations pay tax more that MNCs because of this transfer pricing aggressiveness. With this views, it is germane to empirically examine the effects of transfer pricing aggressiveness on the effective tax rate of MNCs

There are limited literature that examined the effect of transfer pricing on effective tax rate of multinational companies in Nigeria. This paper therefore contributes to the existing literatures by engaging panel data to gauge the effect of transfer pricing on effective tax rate of multinational companies listed on the Nigerian Stock Exchange in Nigeria.

\section{Literature And Theoretical Review}

\section{The Relationship Between Transfer Pricing and Effective Tax Rate}

Transfer pricing refers to the price in which the department or division transfer the goods and services to another department or division within the same organisation at non arm length transaction. 
It is also referred to as the price an enterprise transfers physical goods and intangible properties, and services to other associated enterprises. It a mechanism used by multinational firms to transfer goods and services between their related and associated companies worldwide (Ishola, 2019). Transfer pricing has become a major anticipated challenges worldwide through intercompany financing (service) transactions by tax authorities which has increased significantly in recent years from $7 \%$ (55\%) in 2007 to $42 \%$ (66\%) in 2010 (Chege, 2013). In Nigeria, the implementation of transfer pricing policy is predicated on the need to ensure that related party transaction (international) are accompanied on an arm's length method as prescribed by Section 22 to reduce the incidence of artificially inflating or deflating profit by parent and subsidiary companies operating in different tax environment (Foley, 2012). It is evident that the cost-effective analysis has indicated the mispricing of multinational companies in a related party transaction as a major contributing factor to the erosion of corporate tax revenue (Dean, 2014).

It is also important to note that the nature of transaction that exist between multinational companies in recent years by turning their tax liability into profit is an indication of risk related to transfer pricing (Pearson, 2005). This is further manifested by a decline in the operational tax rates to increase in number of companies reporting a zero or nominal corporate tax liability. The risk involved transfer pricing is considered to be of high priority in Nigeria by the Federal Inland Revenue service Board, which has thus, requested the multinational companies to provide requisite information related to their transfer pricing activities. This is to restructure the financial issues related to the guarantee fees, group loan, type of service provided and received from the related party transaction of the companies.

\section{Effective Tax Rate Measure.}

The Effective Tax Rate is basically the average tax rate a corporation pays on its pre-tax profits and is calculated by dividing a measure of tax liability by a measure of pre-tax income.

\section{EFFTAXR $=$ Measure of tax liability divided by Pre - tax income}

EFFTAXR based measures can be compared with the statutory tax rate. If an EFFTAXR measure is below the statutory tax rate, then it could be an evidence of tax avoidance. The EFFTAXR can be calculated on different measures of tax liability, which could be total tax expense, current tax expense, cash tax expense and pre-tax income, and can vary in terms of periods included in the measure. There are annual ETR measures and long-run EFFTAXR measures.

Effective tax rate (EFFTAXR) is a function of the profit before tax meant to ascertain the company income tax (CIT) and the personal income tax (PIT) as appropriate. It represents a cost to the organization, and as such, drives down their expected profits. Management generally feared the consequences of a non-robust market value indicative of a poor market performance that may lead investors to selling their stakes due to low profit margin. Yao (2013) noted that MNCs with high profit before tax generally shy away from excessive tax liability, claiming consideration of new business expansion for increased capacity and competitiveness, and creating greater opportunities for their firms and shareholders. Thus, they tend to plough back their profits by exploiting intra company transfer pricing to related companies abstaining from the arm's length rules. In line with this argument, Phillips, Pincus, and Rego (2003) highlighted that it is more precise to classify firmyear as successfully avoiding a loss using deferred tax expense over accrual measure, there has been no singular measure that accurately classify firm-years as avoiding reduction in earnings or meeting analyst's predictions. Whereas, Rego (2003) provided empirical evidence recording a negative relationship between pre-tax income and effective tax rate. Given the benefit of learning curve, Rego (2003) observed that firms with regional and international spread have accumulated tax planning expertise that help in reducing their effective tax rate.

\section{Research Hypotheses}

1. $\mathrm{HO}_{1}$ : Transfer pricing has no significant impact on effective tax rate of MNCs

2. HO2: Firm size has no significant impact on effective tax rate of MNCs

3. $\mathrm{HO}_{3}$ : Leverage has no significant impact on effective tax rate of $\mathrm{MNCs}$ 
4. $\mathrm{HO}_{4}$ : Intangible Assets has no significant impact on effective tax rate of MNCs

5. $\mathrm{HO}_{5}$ : Profitability has no significant impact on effective tax rate of MNCs

\section{Theoretical Review \\ The expediency theory}

According to Chigbu et al (2011), this theory asserts that every tax proposal must pass the test of practicability. It must be the only consideration weighing with the authorities in choosing a tax proposal. Economic and social objectives of the state as well as the effects of a tax system should be treated as irrelevant. This proposition has a truth in it, since it is useless to have a tax which cannot be levied and collected efficiently. There are pressures from economic, social and political groups. Every group tries to protect and promote its own interests and authorities are often forced to reshape tax structure to accommodate these pressures. In addition, the administrative set up may not be efficient to collect the tax at a reasonable cost of collection. Taxation provides a powerful set of policy tools to the authorities and should be effectively used for remedying economic and social ills of the society such as income inequalities, regional disparities, unemployment, cyclical fluctuations and so on. This study is anchored on expediency theory because effective tax rate on multinational companies must pass through practical test so as to eschewing corporate tax avoidance.

\section{Review of Related Empirical Literature}

Akinleye, Olaoye and Fajuyagbe (2018) examined the effects of transfer- pricing regulation and compliance on tax administration in Nigeria. The paper uses a descriptive survey research design. Questionnaire was used as the research instrument for data collection. Analyses were made with ordered logit regression, Pearson product moment correlation, variance inflation factor (VIF) and white heteroskedasticity test. Ordered logit regression reveals that transfer- pricing regulation had a tendency to significantly influence tax administration. This study implies that transfer pricing and its compliance has the capacity to improve the effectiveness and efficiency of tax administration in Nigeria. Hence, we concluded that there is poor administration of transfer- pricing tax policy in Nigeria. The study recommended that Federal Inland Revenue Service should put in place not only transfer- pricing laws but adequate machinery in terms of human and technological capital coupled with sensitization on the applicability of the existing transfer- pricing tax policy in Nigeria. However, this study examined the effects of transfer- pricing regulation and compliance on tax administration not on effective tax rate. It was also employed primary source of data in its analysis. Therefore, the results cannot be generalised in wider perspective.

Mutua (2012) examined transfer- pricing management strategies by MNEs and concluded that there is an increased level of tax compliance enforcement, where Nigeria would be forced to conduct TP audits and assessments on MNEs that fail to comply with the rules. He observed that Nigeria has not imposed penalties to companies without TP policies and recommended that there is a need for MNE to understand what TP means and that enlightenment should be carried out on the effects of the levels of inter-company transactions with related companies. He also recommended that there is a need to establish how performance management is measured in MNEs, whether it depends on the levels of sales or otherwise. The study laid much emphasis on transfer- pricing management strategies by MNEs on tax compliance not on effective tax rate. Nonetheless, the results cannot be translated to effective tax rate.

Talab, Flayyih and Yassir (2018) analysed the influence of transfer pricing on financial reporting in global tax from a theoretical point of view. Prior literature was used to develop a construct indicating the degree of focus on the concepts of transfer pricing, the modern way of transfer pricing way, the purpose of transfer pricing, the most common transfer pricing methods, determination and clarification as regards transfer pricing issues, the rules of transfer pricing and its future consequence and an overview transfer pricing in some selected countries. The results from literature review and an analysis of global tax in MNES show that some rules of transfer pricing as recommended by OECD provide the next conditions that a transaction must meet to fall below the transfer pricing principles. Multinational organizations can be of a very planned advantage by having a parent company (the head office) and venture/associates or subsidiaries operating in other 
countries/locations as a consolidated entity which linked companies (head offices and its associate/joint/ a subsidiary) taking its activities in different states/nations. However, the scope of the study is limited to OECD not extended to Nigeria, therefore the results deducted from the study cannot be given wider perspective.

Liu, Schmidt-Eisenlohr and Dongxian (2017) examined the international transfer pricing and tax avoidance in UK. The study employs unique data on export transactions and corporate tax returns of UK multinational firms and finds that firms manipulate their transfer prices to shift profits to lower-taxed destinations. It uncovers three new findings on tax-motivated transfer mispricing in real goods. First, transfer mispricing increases substantially when taxation of foreign profits changes from a worldwide to a territorial approach in the UK, with multinationals shifting more profits into lowtax jurisdictions. Second, transfer mispricing increases with a firm's R\&D intensity. Third, taxmotivated transfer mispricing is concentrated in countries that are not tax havens and have low-tomedium-level corporate tax rates. Notwithstanding, this study was carried out in UK not in Nigeria, therefore, the result is restricted to UK not Nigeria.

From the review of extant literatures, the gaps identified are scope, methodology and conceptual gap. This is because majority of the studies seen and reviewed are conducted in Nigeria with different scope, methodology and concepts, and the findings may not be generalized in wider perspectives. Thus, this study is exclusive and anticipates to contribute to knowledge by employing panel data analysis to examine empirically the effects of transfer pricing aggressiveness on the effective tax rate of MNCs listed on the Nigerian Stock Exchange in Nigeria

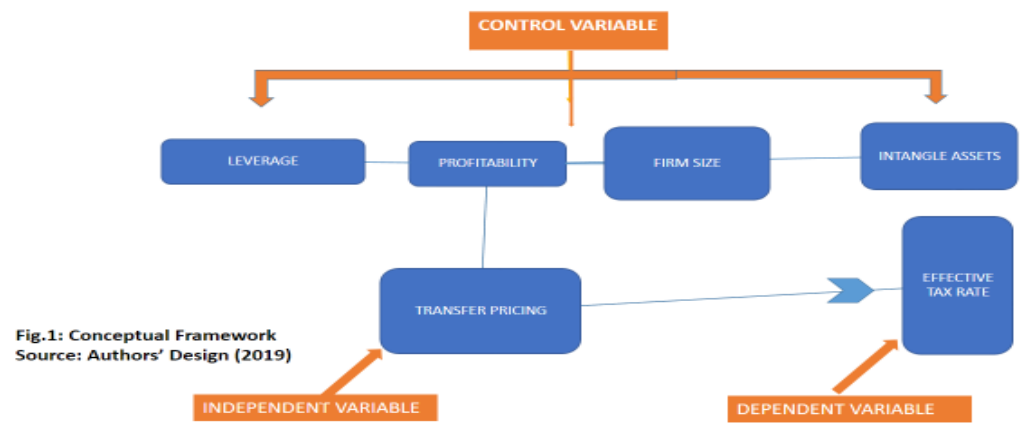

Source: Author's Design (2019)

\section{METHODOLOGY}

Fifty selected multinational company listed in Nigerian stock exchange that have their subsidiary in more than one country were selected from 2009 to 2018. The data collected from the selected companies' annual reports from 2009 to 2018 are the values of the company size, profitability, intangible assets and leverages. Borrowings, receivables, payables, and related party transactions were also extracted and used as an index to measure transfer pricing adopted from Asher and Rajan, (2001).

\section{Model Specification}

$$
\text { EFFTAXR }=\alpha_{0}+\alpha_{1} \text { TRPRIC }+\alpha_{2} \text { COYSIZ }+\alpha_{3} \text { PROFT }+\alpha_{4} L E V E R A G+\alpha_{5} I N T G B+\varepsilon
$$

Where:

EFFTAXR
TRPRIC
COYSIZ
PROFT
LEVERAG
INTGB
$\varepsilon$

$\mathcal{\varepsilon}$

\author{
= Effective Tax Rate, \\ $=$ Transfer pricing, \\ = Firm size ( Natural log of total Assets), \\ $=$ Profitability (pre-tax income), \\ = Leverages (long time debt divided by Equity), \\ $=$ Intangible (Natural log of $R \& D$ expenditure) \\ = Error term.
}


RESULT AND DISCUSSION

Table 1. Descriptive Statistics On The Effect Of Transfer Pricing On Effective Tax Rate In Nigeria

\begin{tabular}{cccccc}
\hline Variables & OBS & Mean & Std. Dev & Min & Max \\
\hline EFFTAXR & 500 & $1.36 \mathrm{e}+07$ & $1.50 \mathrm{e}+07$ & 945636 & $8.28 \mathrm{e}+07$ \\
TRPRIC & 500 & $4.18 \mathrm{e}+07$ & $4.52 \mathrm{e}+07$ & 24429 & $2.09 \mathrm{e}+08$ \\
COYSIZ & 500 & $2.95 \mathrm{e}+07$ & $3.12 \mathrm{e}+07$ & 1200351 & $1.42 \mathrm{e}+08$ \\
PROFT & 500 & $1.05 \mathrm{e}+07$ & $1.64 \mathrm{e}+07$ & 373000 & $1.27 \mathrm{e}+08$ \\
LEVERAG & 500 & $2.00 \mathrm{e}+08$ & $2.40 \mathrm{e}+08$ & 4248697 & $1.13 \mathrm{e}+09$ \\
INTGB & 500 & $7.09 \mathrm{e}+07$ & $1.18 \mathrm{e}+08$ & 55603 & $5.50 \mathrm{e}+08$ \\
\hline
\end{tabular}

Source: Researcher's Computation (2019)

The descriptive statistics of the analysis is presented in Table 1 above shows that effective tax rate (EFFTAXR) as the dependent variable. EFFTAXR had a mean value of $1.36 \mathrm{e}+07$ with a standard deviation of $1.50 \mathrm{e}+07$, it had a maximum value of $8.28 \mathrm{e}+07$ and a minimum value of 945636. TRPRIC had a mean of $4.18 \mathrm{e}+07$ and standard deviation of $4.52 \mathrm{e}+07$ with positive maximum and minimum value of $2.09 \mathrm{e}+08$ and 24429 respectively, which signifies that for every $1 \%$ reduction in effective tax rate, transfer pricing is responsible for $4.1 \%$, this implies that there is a negative relationship between effective tax rate and transfer pricing.

The impact of building and other assets can be seen as shown in the Table 1, COYSIZ, PROFT, LEVERAG, and INTGB with mean values of $2.95 \mathrm{e}+07,2.05 \mathrm{e}+07,2.00 \mathrm{e}+08$, and $7.09 \mathrm{e}+07$ respectively and standard deviations of $3.12 \mathrm{e}+07,2.64 \mathrm{e}+07,2.40 \mathrm{e}+08$ and $1.18 \mathrm{e}+08$ having positive maximum values of $1.60 \mathrm{e}+07,1.13 \mathrm{e}+09$ and $5.50 \mathrm{e}+08$; and positive minimum values of 1200351,373000 , 4248697 and 55603. This implies that $1 \%$ increase in COYSIZ, LEVERAG, and INTGB triggers a decrease in effective tax rate because mean value is greater than 2.00. Nonetheless, $1 \%$ increase in PROFT increases effective tax rate because mean value is less than 2.00. It can be deduced from the analysis that there is a negative relationship between effective tax rate and independent variables ( COYSIZ, LEVERAG, and INTGB).

Table 2. Pooled effect Model on effect of Transfer Pricing on Effective tax rate in Nigeria

\begin{tabular}{|c|c|c|c|c|c|c|}
\hline $\begin{array}{l}\text { Dependent } \\
\text { variables }\end{array}$ & $\begin{array}{l}\text { Independent } \\
\text { variables }\end{array}$ & Coefficient & $\begin{array}{l}\text { Standard } \\
\text { error }\end{array}$ & $\mathbf{T}$ & $\mathbf{P}>/ \mathbf{T} /$ & (95\% conf. Interval) \\
\hline \multirow[t]{6}{*}{ EFFTAXR } & TPRIC & -.0539232 & 0.011230 & -4.80 & 0.001 & -.2789921 \\
\hline & COYSIZ & -.1748913 & 0.052051 & -3.36 & 0.005 & -.4298817 \\
\hline & LEVERAG & -.0810307 & 0.020308 & -3.99 & 0.003 & -.2055241 \\
\hline & PROFT & .0421892 & 0.007325 & 5.76 & 0.000 & -.0304596 \\
\hline & INTGB & -.0101412 & 0.001737 & -5.84 & 0.000 & -.0264722 \\
\hline & CONSTANT & 9.110556 & 0.831255 & 10.96 & 0.000 & $1.73 \mathrm{e}+07 \quad 2.49 \mathrm{e}+07$ \\
\hline \multirow[t]{2}{*}{ R-squared } & $=0.6445$ & \multirow{2}{*}{\multicolumn{3}{|c|}{ Adj R-squared = 0.6043}} & \multicolumn{2}{|c|}{ Prob $>\mathrm{F} \quad=0.0001$} \\
\hline & & & & & $\mathrm{F}(5,94)$ & $=136.08$ \\
\hline
\end{tabular}

Source: Researcher's Computation (2019)

The Table 2 showed the effect of Transfer Pricing, firm size, profitability, leverages, and intangible assets on Effective tax rate in Nigeria. $1 \%$ increase in Transfer Pricing (TRPRIC) reduces effective tax rate (EFFTAXR) by $0.05 \%$, it shows that there is a negative significant effect of TRPRIC on EFFTAXR $(\beta=-.0539232, \mathrm{t}=0.001<0.05) .1 \%$ increase in COYSIZ also reduces EFFTAXR by $0.17 \%$, it predicated that there is a negative significant effect of COYSIZ on EFFTAXR $(\beta=-.1748913, \mathrm{t}=0.005<0.05)$. Also, $1 \%$ increase in LEVERAG reduces EFFTAXR by $0.081 \%$, it shows that there is a negative significant effect of LEVERAG on EFFTAXR $(\beta=-$ 
$.0810307, \mathrm{t}=0.003<0.05) .1 \%$ increase in PROFT increases EFFTAXR by $0.042 \%$, it shows that there is a positive significant effect of PROFT on EFFTAXR $(\beta=.0421892, t=0.000<0.05) .1 \%$ increase in intangible assets (INTGB) reduces EFFTAXR by $0.010 \%$, it shows that there is a negative significant effect of intangible assets on EFFTAXR $(\beta=-.0101412, t=0.000<0.05)$.

Given the coefficient of determination $\left(\mathrm{R}^{2}\right)$ as 0.6445 which is $64 \%$ supported by adjusted $\mathrm{R}^{2}$ as $50.4 \%$, it predicates that the independent variables incorporated into this model were able to explain the effect of Transfer Pricing, firm size, profitability, leverages, and intangible assets on Effective tax rate in Nigeria to $60 \%$. That is, there is a significant effect of independent variables (Transfer Pricing, firm size, leverages, and intangible assets) on Effective tax rate in Nigeria. The F Probability statistic also confirms the significance of this model. The adjusted $\mathrm{R}^{2}$ of 0.6043 indicates that about $60.4 \%$ of total variation in the dependent variable is accounted for by the explanatory variables at level of 0.05 level of significance while the remaining $39.6 \%$ are for error terms.

The hypothesis that Transfer pricing has no significant impact on effective tax rate of MNCs should be rejected because $\beta=-.0539232, t=0.001<0.05$ significant level, therefore transfer pricing has negative significant impact on effective tax rate of MNCs. In the same vein, the hypothesis that Firm size has no significant impact on effective tax rate of MNCs was also rejected because $\beta=$ $.1748913, \mathrm{t}=0.005<0.05$, therefore firm size has negative significant impact on effective tax rate of MNCs. Other hypotheses which postulated that Leverage, Intangible Assets and Profitability have no significant impact on effective tax rate were also rejected because $\beta=-.0810307 ; .0421892$, $.0101412, \mathrm{t}=0.005 ; 0.003 ; 0.000 ; 0.000<0.05$ sig. level respectively. Therefore, Leverage and Intangible Assets also have negative significant impact on Effective tax rate of MNCs.

Table 3. Effect of Transfer Pricing on Effective Tax Rate in Nigeria Using Random Effect Model

\begin{tabular}{|c|c|c|c|c|c|c|}
\hline $\begin{array}{l}\text { Dependent } \\
\text { variable }\end{array}$ & $\begin{array}{l}\text { Independent } \\
\text { variables }\end{array}$ & Coefficient & $\begin{array}{l}\text { Standard } \\
\text { error }\end{array}$ & $\mathbf{T}$ & $\mathbf{P}>/ \mathbf{T} /$ & (95\% conf. Interval) \\
\hline \multirow[t]{6}{*}{ EFFTAXR } & TRPRIC & -.0575884 & 0.0083643 & -6.89 & 0.000 & -.2784952 \\
\hline & COYSIZ & -.1781420 & 0.0372922 & -4.78 & 0.003 & -.4279581 \\
\hline & LEVERAG & -.0755239 & 0.0189912 & -3.98 & 0.006 & $\begin{array}{ll}-.1985492 & .0475014\end{array}$ \\
\hline & PROFT & .0417251 & 00112411 & 3.70 & 0.008 & $\begin{array}{ll}-.029271 & .0387212\end{array}$ \\
\hline & INTGB & -.0108665 & 0.0018734 & -5.80 & 0.001 & -.0257099 \\
\hline & CONSTANT & 9.110786 & 0.8848462 & 10.30 & 0.000 & $1.71 \mathrm{e}+07 \quad 2.51 \mathrm{e}+07$ \\
\hline \multicolumn{2}{|c|}{$\begin{array}{l}\text { R-sq: within }=0.6684 \\
\text { between }=0.7725 \\
\text { overall }=0.7444\end{array}$} & \multicolumn{3}{|c|}{\begin{tabular}{l|l} 
sigma_u & 1975170.3 \\
sigma_e & 13267341 \\
rho & $.02168307 \quad$ (fra
\end{tabular}} & \multicolumn{2}{|c|}{$\begin{array}{l}\text { Wald chi } 2(5)=28.53 \\
\text { corr }\left(\mathrm{u} \_\mathrm{i}, \mathrm{X}\right)=0 \text { (assumed) } \\
\text { Prob }>\text { chi2 }=0.0000\end{array}$} \\
\hline
\end{tabular}

Source: Researcher's Computation (2019)

Random effect needs to be tested because of the doubt that may arise with pooled result. Table 3 showed the effect of Transfer Pricing, firm size, profitability, leverages, and intangible assets on Effective tax rate in Nigeria by Random effects model results. $1 \%$ increase in Transfer Pricing (TRPRIC) reduces Effective tax rate (EFFTAXR) by $0.057 \%$, it shows that there is a negative significant effect of TRPRIC on EFFTAXR $(\beta=-.0575884, \mathrm{t}=0.000<0.05) .1 \%$ increase in COYSIZ also reduces EFFTAXR by $0.17 \%$, it shows that there is a negative significant effect of COYSIZ on EFFTAXR $(\beta=-.178142, \mathrm{t}=0.003<0.05)$. Also, $1 \%$ increase in LEVERAG reduces EFFTAXR by $0.075 \%$, it shows that there is a negative significant effect of LEVERAG on EFFTAXR $(\beta=-.0755239, \mathrm{t}=0.006<0.05) .1 \%$ increase in PROFT increases EFFTAXR by $0.041 \%$, it shows that there is a positive significant effect of PROFT on EFFTAXR $(\beta=.0417251$ , $\mathrm{t}=0.008<0.05$ ). $1 \%$ increase in intangible assets (INTGB) reduces EFFTAXR by $0.010 \%$, it shows that there is a negative significant effect of intangible assets on EFFTAXR $(\beta=-.0108665, \mathrm{t}$ $=0.001<0.05$ ). 
Random effect model also advocated the rejection of hypotheses by pooled effect model results in Table 2. The hypothesis that Transfer pricing has no significant impact on effective tax rate of MNCs was also rejected because $-.0575884, \mathrm{t}=0.000<0.05$, that is less than 0.005 significant level, therefore transfer pricing has negative significant impact on effective tax rate of MNCs. In the same vein, the hypothesis that Firm size has no significant impact on effective tax rate of MNCs was rejected because $\beta=-.178142, t=0.003<0.05$, therefore firm size has negative significant impact on effective tax rate of MNCs. Other hypotheses which postulated that Leverage, Intangible Assets and Profitability have no significant impact on effective tax rate were absolutely rejected because $\beta=-.0755239 ; .0417251,-.0108665, \mathrm{t}=0.003 ; 0.006 ; 0.000 ; 0.008<0.05$ sig. level respectively. Therefore, Leverage and Intangible Assets also have negative significant impact on Effective tax rate of MNCs. With this outcome, MNCs have been tactically setting an artificial intercompany transfer prices in order to facilitate corporate tax avoidance.

Table 4. Effect of Transfer Pricing on Effective Tax Rate in Nigeria using Fixed Effect Model

\begin{tabular}{|c|c|c|c|c|c|c|c|}
\hline \multirow{2}{*}{$\begin{array}{l}\text { Dependent } \\
\text { variable } \\
\text { EFFTAXR }\end{array}$} & \multirow{2}{*}{$\begin{array}{l}\text { Independent } \\
\text { variables } \\
\text { TRPRIC }\end{array}$} & \multirow{2}{*}{$\begin{array}{l}\text { Coefficient } \\
-.0760069\end{array}$} & \multirow{2}{*}{$\begin{array}{l}\text { Standard } \\
\text { error } \\
0.011516\end{array}$} & $\mathbf{T}$ & $\mathbf{P}>/ \mathbf{T} /$ & \multicolumn{2}{|c|}{ (95\% conf. Interval) } \\
\hline & & & & - & 0.000 & -.3056174 & .1536037 \\
\hline & COYSIZ & -1953082 & & $\begin{array}{l}6.60 \\
-\end{array}$ & 0.001 & -4519363 & 06132 \\
\hline & & & 0.0382215 & 5.11 & & & \\
\hline & LEVERAG & -.0479302 & & - & 0.000 & -.1801775 & .0843171 \\
\hline & & & 0.0066394 & 7.22 & & & \\
\hline & PROFT & .0781069 & 0.0188664 & 4.14 & 0.003 & -.0277382 & .043352 \\
\hline & INTGB & -.0154521 & & - & 0.002 & -.0270196 & .0579237 \\
\hline & & & 0.0032813 & 4.71 & & & \\
\hline & CONSTANT & 9.090745 & 1.0225816 & 8.89 & 0.000 & $1.62 \mathrm{e}+07$ & $2.55 \mathrm{e}+07$ \\
\hline \multirow{2}{*}{\multicolumn{2}{|c|}{$\begin{array}{l}\text { R-sq: within }=0.6711 \\
\text { between }=0.8420 \\
\text { overall }=0.8408\end{array}$}} & & \multirow{2}{*}{\multicolumn{2}{|c|}{ Prob $>F=0.0000$}} & \multicolumn{3}{|c|}{\begin{tabular}{l|r} 
sigma_u & 4616693.3 \\
sigma_e & 13267341
\end{tabular}} \\
\hline & & & & & $\begin{array}{l}\text { rho | } .1 \\
\text { variance }\end{array}$ & $\begin{array}{l}0800784 \\
\text { due to u_i) }\end{array}$ & fraction of \\
\hline
\end{tabular}

Source: Researcher's Computation (2019)

Table 4 showed the effect of Transfer Pricing, firm size, profitability, leverages, and intangible assets on Effective tax rate in Nigeria by Fixed effects model results. 1\% increase in Transfer Pricing (TRPRIC) reduces Effective tax rate (EFFTAXR) by $0.076 \%$, it shows that there is a negative significant effect of TRPRIC on EFFTAXR $(\beta=-.0760069, \mathrm{t}=0.000<0.05) .1 \%$ increase in COYSIZ also reduces EFFTAXR by $0.19 \%$, it shows that there is a negative significant effect of COYSIZ on EFFTAXR $(\beta=-.1953082, \mathrm{t}=0.001<0.05)$. Also, $1 \%$ increase in LEVERAG reduces EFFTAXR by $0.047 \%$, it shows that there is a negative significant effect of LEVERAG on EFFTAXR $(\beta=-.0479302, \mathrm{t}=0.003<0.05) .1 \%$ increase in PROFT increases EFFTAXR by $0.078 \%$, it shows that there is a positive significant effect of PROFT on EFFTAXR $(\beta=.0781069$ , $\mathrm{t}=0.003<0.05$ ). $1 \%$ increase in intangible assets (INTGB) reduces EFFTAXR by $0.015 \%$, it shows that there is a negative significant effect of intangible assets on EFFTAXR $(\beta=-.0154521, t$ $=0.002<0.05$ ).

Fixed effects model also upheld the rejection of the stated hypotheses. The hypothesis that Transfer pricing has no significant impact on effective tax rate of MNCs was also rejected by Fixed effects model because $-.0760069, \mathrm{t}=0.000<0.05$ significant level, therefore transfer pricing has negative significant impact on effective tax rate of MNCs. In the same vein, the hypothesis that Firm size has no significant impact on effective tax rate of MNCs should be rejected because $\beta=$ $.1953082, \mathrm{t}=0.001<0.05$, therefore firm size has negative significant impact on effective tax rate of MNCs. Other hypotheses which postulated that Leverage, Intangible Assets and Profitability have no significant impact on effective tax rate were rejected emphatically because $\beta=-.0479302$; 
0781069, -.0154521, $\mathrm{t}=0.003 ; 0.003 ; 0.002<0.05$ sig. level respectively. Therefore, Leverage and Intangible Assets also have negative significant impact on Effective tax rate of MNCs.

Table 5. Hausman Test on the Effect of Transfer Pricing on Effective Tax Rate in Nigeria

\begin{tabular}{|c|c|c|c|c|c|}
\hline $\begin{array}{l}\text { Dependent } \\
\text { variable }\end{array}$ & $\begin{array}{l}\text { Independent } \\
\text { variables }\end{array}$ & $\begin{array}{l}\text { Coefficient } \\
\text { (b) }\end{array}$ & $\begin{array}{l}\text { Coefficient } \\
\text { (B) }\end{array}$ & $\begin{array}{l}\text { (b-B) } \\
\text { Difference }\end{array}$ & $\begin{array}{l}\text { Sqrt (diag (v- } \\
\text { b-v-B)) S.E }\end{array}$ \\
\hline \multirow[t]{2}{*}{ EFFTAXR } & TRPRIC & -.0760069 & -.0575884 & -.0184185 & .0251553 \\
\hline & $\begin{array}{l}\text { COYSIZ } \\
\text { LEVERAG } \\
\text { PROFT }\end{array}$ & $\begin{array}{c}-.1953082 \\
-.0479302 \\
.0078069\end{array}$ & $\begin{array}{l}-.178142 \\
-.0755239 \\
.0047251\end{array}$ & $\begin{array}{r}-.0171662 \\
.0275937 \\
.0030818\end{array}$ & $\begin{array}{l}.0203332 \\
.0220027 \\
.0043295\end{array}$ \\
\hline $\begin{array}{l}\mathrm{b}=\text { consistent } \\
\text { under Ho and } \\
\mathrm{Ha} \text {; }\end{array}$ & $\begin{array}{l}\text { INTGB } \\
\text { B = inconsisten } \\
\text { efficient under } \\
\text { Ho }\end{array}$ & $\begin{array}{l}-.0154521 \\
\text { under Ha, }\end{array}$ & $\begin{array}{l}-.0108665 \\
\text { Test: Ho: } \\
\text { systematic } \\
\text { chi2 } 2(5)= \\
\\
\quad \text { Prob }>\end{array}$ & $\begin{array}{l}-.0045856 \\
\text { difference in } \\
\text { (b-B)' }\left[\left(\mathrm{V} \_b-\mathrm{V}\right.\right. \\
=\quad 3.71 \\
\text { chi } 2=\quad 0.592\end{array}$ & $\begin{array}{l}.0103941 \\
\text { coefficients not } \\
\left.\text { B })^{\wedge}(-1)\right](b-B)\end{array}$ \\
\hline
\end{tabular}

Source: Researchers' Computation (2019)

To decide between fixed or random effects, Hausman test was conducted where the null hypothesis is that the preferred model is random affects vs. the alternative the fixed effects (Green, 2008). It basically tests whether the unique errors $(u i)$ are correlated with the regressors, the null hypothesis is they are not. If Chi2 $<0$ is greater than 0.05 (i.e. significant), random effects should be considered, but otherwise, fixed effect should be considered. Therefore the null hypothesis is rejected.

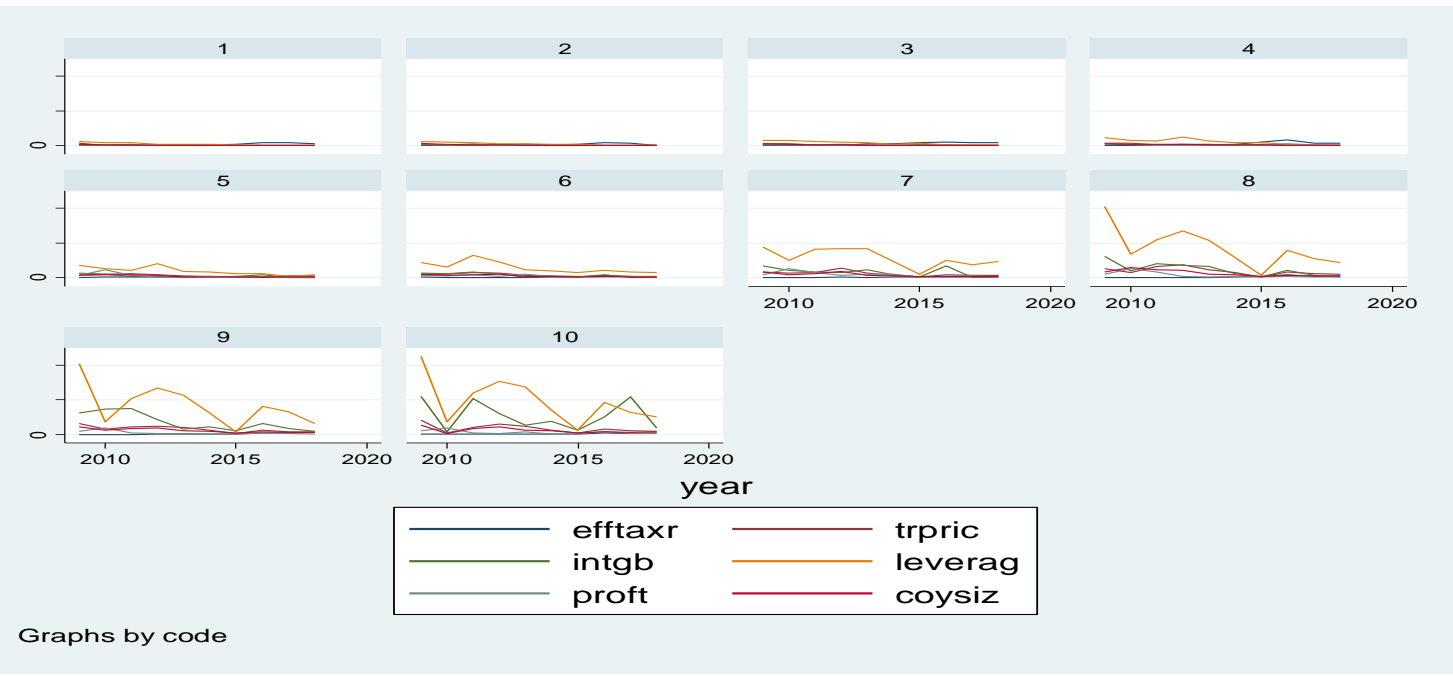

Fig 2. Panel Analysis Plots on the Effect of Transfer Pricing on Effective Tax Rate in Nigeria

Table 6. Relationship between Transfer Pricing and Effective Tax Rate in Nigeria

\begin{tabular}{lllllll}
\hline & EFFTAXR & TRPRIC & COYSIZ & LEVERAG & PROFT & INTGB \\
\hline EFFTAXR & 1.0000 & & & & & \\
TRPRIC & $-0.4361^{*}$ & 1.0000 & & & & \\
COYSIZ & $-0.4750^{*}$ & $0.9255^{*}$ & 1.0000 & & & \\
LEVERAG & $-0.3918^{*}$ & $0.9385^{*}$ & $0.8696^{*}$ & 1.0000 & & \\
PROFT & $0.3557^{*}$ & $0.4148^{*}$ & $0.5381^{*}$ & $0.3229^{*}$ & 1.0000 & \\
\hline
\end{tabular}




\begin{tabular}{lllllll}
\hline INTGB & $-0.2984^{*}$ & $0.7452^{*}$ & $0.7243^{*}$ & $0.7823^{*}$ & $0.3667^{*}$ & 1.0000 \\
\hline
\end{tabular}

Source: Researchers' Computation (2019)

The correlation result of Pearson pairwise in the table 6. Effective tax rate had negative significant relationship with TRPRIC, COYSIZ, LEVERAG, and INTAG $\left(-0.4361^{*},-0.4750^{*}\right.$, $\left.0.3918^{*},-0.2984^{*}\right)$ but positive significant relationship with Profitability $\left(0.3557^{*}\right)$. The results confirmed that EFFTAXR is negatively and significantly linked with the transfer pricing, company size, leverage and intangible asset.

\section{SUMMARY AND CONCLUSION}

This study examined the effect of Transfer Pricing on Effective tax rate of selected multinational companies in Nigeria. Secondary data were obtained from annual published reports of selected multinational companies listed in Nigeria stock exchange from 2009 to 2018. The panel data analysis results showed that firm size, leverages, Intangible asset, Transfer pricing had negative significant effect on effective tax rate in Nigeria. This predicted that company utilised Transfer Pricing, Leverage, Firms Size and Intangible Assets to eschew or reduce effective tax rate in Nigerian firms. Also, most of the quoted firms tactically setting an artificial inter-company transfer prices in order to facilitate corporate tax avoidance. Therefore it is recommended that the government should exert vigorous action on arm's length transaction law by carefully monitoring and comparing the transfer price within the same companies with the price stated for external customers of the companies so as to bridge the tax loophole established by the transfer pricing. If this is effectively done, companies will not be able to tactically setting an artificial inter-company transfer prices in order to reduce effective tax rate.

\section{REFERENCES}

Alabi O. G., Adetunji B. M., \& Olawale O. E. (2011). An analysis of China-Nigeria investment relations. Journal of Chinese Economic and Foreign Trade Studies, 4(3), 183-199.

Akinleye G.T. Olaoye C.O. \& Fajuyagbe B.S. (2018). Effects of Transfer Pricing Regulations and Compliance on Tax Administration in Nigeria. Acta Universitatis

Danubius , 14( 5): 86-97.

Asher, M. G., \& Rajan, R. S. (2001). Globalization and tax systems: Implications for developing countries with particular reference to Southeast Asia. ASEAN Economic Bulletin, 119-139.

Bartelsman, E. J., \& Beetsma, R. M. W. J. (2003). Why pay more? Corporate tax avoidance through transfer pricing in OECD countries. Journal of Public Economics, 87(9-10), 2225-2252. doi: http://dx.doi.org/10.1016/S0047-2727(02)00018-X

Chege, P. N. (2013). The Organisation Of Economic Cooperation And Development (OECD) Transfer Pricing Guidelines: An Evaluation Of Their Effectiveness In The Kenya's Tax Regime. (Master of Law Desertation ), University of Nairobi, University of Nairobi Kenya.

Cunningham, R. (2014). The comprehensive guide to the world's leading transfer pricing firms. International Tax Review.

Dean, K. A. (2014). Transfer pricing: an evaluation of section 31 of the Income Tax Act. (Master of Law), University of Cape Town, South Africa.

Dyreng, S. D., Hanlon, M., \& Maydew, E. L. (2008). Long-run corporate tax avoidance. The accounting review, 83(1), 61-82.

Elitzur, R., \& Mintz, J. (1996). Transfer pricing rules and corporate tax competition. Journal of Public Economics, 60(3), 401-422. doi: http://dx.doi.org/10.1016/0047-2727(95)01558-2 
Foley, S. (2012). Transfer Pricing - A Rising New Dawn in Nigeria. Global Head of Transfer Pricing Services.

Grubert, H. (2003). Intangible income, intercompany transactions, income shifting, and the choice of location. National Tax Journal, 221-242.

Hopwood, P. (2013). Tracking the trends in 2013-the top 10 issues mining companies may face: hot topic. Inside Mining, 6(1), 16-18.

Isau, A. O. (2014). Transfer Pricing The Nigerian Perspective. International Journal of Accounting ad Taxation, 2(2), 23-38.

Isola K.A. (2019). Taxation Principles and Fiscal Policy in Nigeria. Kastas Publishers, 2nd Edition, pp 928-930.

Kabir, M. M. (2012). Transfer Pricing Regulation in Nigeria

Keuschnigg, C., \& Devereux, M. P. (2013). The arm's length principle and distortions to multinational firm organization. Journal of International Economics, 89(2), 432-440.

Klassen, K. J., Lisowsky, P., \& Mescall, D. (2013). Transfer pricing: Strategies, practices, and tax minimization. Practices, and Tax Minimization (April 29, 2013).

Liu, L. Schmidt-Eisenlohr T.and Dongxian G.(2017). The international transfer pricing and tax avoidance in UK. Paper presented at Federal Reserve Board, University of

Michigan, University of Oxford, CESifo Global Economy Conference, and Southern

Economic Association 2016 Conference

McDonald, M. (2008). Income Shifting from Transfer Pricing: Further Evidence from Tax Return Data.

Mills, L., Erickson, M. M., \& Maydew, E. L. (1998). Investments in tax planning. The Journal of the American Taxation Association, 20(1), 1.

Mutua, N (2012). Transfer pricing management strategies by MNEs within the main investments segment of NSE. MBA research project, University of Nairobi, 23-26.

Newberry, K. J., \& Dhaliwal, D. S. (2001). Cross-jurisdictional income shifting by US multinationals: Evidence from international bond offerings. Journal of Accounting Research, 643-662.

Nwogugu, M. C. (2014). Politics, Systemic Risk and Illiquid Cross-Listings: The Case of the Us Gdr Model, and the Russian Sanctions-Response Model as Applied in Nigeria. Available at SSRN.

Oladun, M. M. (2012). Innovative Distribution Stratagies and Performance of Selected Multinational Corporations (MNCs) and Domestic Manufacturing Firms in Nigeria. (Doctor of Phylosophy ), Covenant University, Convenant University.

Pastukhov, O. (2006). International Taxation of Income Derived from Electronic Commerce: Current Problems and Possible Solutions. BUJ Sci. \& Tech. L., 12, 310.

Pearson, T. C. (2005). Preparing Multinational Companies for Transfer Pricing Audits of Intangibles. International low \& Management Review., 2, 159. 
Pendse, S. J. (2012). International transfer pricing: A review of non-tax outlook. Procedia-Social and Behavioral Sciences, 37, 337-343.

Phillips, J., Pincus, M., \& Rego, S. O. (2003). Earnings management: New evidence based on deferred tax expense. The accounting review, 78(2), 491-521.

Rego, S. O. (2003). Tax-Avoidance Activities of U.S. Multinational Corporations*. Contemporary Accounting Research, 20(4), 805-833. doi: 10.1506/VANN-B7UB-GMFA-9E6W

Richardson, G., Taylor, G., \& Lanis, R. (2013). Determinants of transfer pricing aggressiveness: Empirical evidence from Australian firms. Journal of Contemporary Accounting \& Economics, 9(2), 136-150.

Singh, R. (2008). The review of the Glaxo decision and topical issues in transfer pricing. (Master of Business Administration Doctoral dissertation), Auckland University of Technology. (1-108)

Slemrod, J. (2001). A general model of the behavioral response to taxation. International Tax and Public Finance, 8(2), 119-128.

Swenson, D. L. (2001). Tax Reforms and Evidence of Transfer Pricing. National Tax Journal, 54(1), 7-25. doi: $10.2307 / 41789532$

$\begin{array}{llllllll}\text { Talab, H. } & \text { T. } & \text { Flayyih H. } & \text { H } & \text { Y } & \text { Yassir } & \text { Y. N.(2018) }\end{array}$ https://www.researchgate.net/publication/322702566_transfer_pricing_and_its_effect_on_fi nancial_reporting_a_theoretical_analysis_of_global_tax_in_multinational_companies

Urquidi, A. J. (2008). An introduction to transfer pricing. New School Economic Review, 3(1), $27-$ 45.

Yao, J.-T. (2013). The arm's length principle, transfer pricing, and location choices. Journal of Economics and Business, 65(0), 1-13. doi: http://dx.doi.org/10.1016/j.jeconbus.2012.09.004 